\title{
Caring Caresses and the Embodiment of Good Teaching
}

Stephen J. Smith, Simon Fraser University, Burnaby, BC, Canada Email: stephen_smith@sfu.ca

\begin{abstract}
Attention is drawn to the movements of the body and to the ethical imperative that emerges in compelling, flowing moments of teaching. Such moments of teaching are not primarily intellectual, discursive events, but physical, sensual experiences in which the body surrenders to its own movements. Teaching is recognized momentarily as a carnal intensity embedded in and emerging from the flesh. The ethical imperative to this teaching is felt proprioceptively and kinaesthetically when one holds in self-motion the well-being of another as being of the same flesh. The teaching caress offers a primary example. This gesture of intimacy discloses an embodied ethic that contrasts with the transcendental ethics of curricular prescriptions, professional codes of conduct, and the presumptions of self-monitoring behavior. It is a gesture of care for another person, without fastidious carefulness. It is a gesture of pure duration, without sanctimonious purity, in its contact with the beauty, truth and value of the teachable moment. From earliest engagements with children to the dynamics of the university classroom, what makes for good teaching is essentially attentiveness to intimate gestures, such as the caress, that guide teachers kinethically in the moment.
\end{abstract}

\section{Introduction}

Ever since Maurice Merleau-Ponty drew attention to the lived body, flesh as an incarnate principle of engagement with the world, and motility as intercorporeal meaning-making, a phenomenology of embodiment has provided a basis for recognizing teaching as a fundamentally situated, relational and gestured encounter. Merleau-Ponty's analyses have been elaborated and critiqued in poststructuralist and feminist circles, with the result that a phenomenology of embodiment, which attends in particular to gendered, abject, medicalized, technologized, marginalized and sexualized bodies, lies at hand for interrogating the material along with the social and political conditions of teaching. Extending these lived body analyses into the realms of desire, eros, intimacy and affection, phenomenology has traced the configuration of teaching from our earliest engagements with children to the dynamics of the university classroom. Representative of this range of applications are Max van Manen's (1991) study of "pedagogical tact” that is exercised in teaching children, Erica McWilliam's (1994) “(s)education” of youth, Celeste Snowber’s (2006) “curriculum of longing” for all ages, and Jane Gallop's (1995), Regina Barreca's and Deborah Morse's (1997) “erotics of instruction” in college settings. 
What appears to be missing in this fleshing-out of teaching is a basis for deciding what is good about it. Beyond arguments that good teaching meets external standards for student learning, that it accords with the state of readiness of the learner, or that it conforms to measures of instructional effectiveness, principles of self-monitoring behavior or codes of professional conduct, the recognition of the bodily constitution of the educative event begs the question of what makes any particular event meaningful and beneficially significant. It is not enough to observe the canons of good teaching, even the standards of care for children and youth, as requisite for embracing what is good about teaching. The basis of good teaching requires a more fundamental understanding of a bodily sensibility that is lived, felt and experienced intensely. For such an understanding we must eschew transcendental ethics in favor of further phenomenological investigation of the "bodily imperatives" (see Lingis, 1994, 1998, 2000; Levinas, 1969) caught in the acts, postures and gestures of teaching - those "bodily imperatives that emerge out of our intercorporeal exchanges” (Weiss, 1999).

This paper focuses on certain gestural aspects of teacher motility wherein the ethical question arises as to whether the learner's interests are being best served. Momentary gestures, fleeting exchanges, the durations of a touch, a look, a smile, are difficult to grasp with ethical certainty, but that is precisely the point of an ethics of the flesh. The task of phenomenological analysis is to catch the question of 'What makes for good teaching?' within the intercorporeal constitution of the lived, gestured teaching event. It is to discern within the movements of the flesh-and-blood teacher the kinesthetic and proprioceptive senses of good teaching. It is to establish an ethical sensibility within kinesthetic consciousness (Sheets-Johnstone, 2008, 2011), a sense of what is proper within proprioception (Milloy, 2007), and a grasp of what is right to do in writing about the most viscerally, kinesthetically and proprioceptively felt gestures of teaching (van Manen, 1991, pp. 181-183). Writing from the teaching body, I seek to establish an embodied ethics that might guide teachers beyond curricular prescriptions, professional codes of ethics, and the presumptions of self-monitoring behavior.

This writing is of a pedagogy of intimacy and not a pedagogy premised on distant relations to children and youth. I describe a pedagogy that embraces, caresses and kisses the child, that touches the child, that reaches out and makes the world tangible, that enables the child to be at home in the world, a pedagogy grounded in the gestures of living with children. It is a pedagogy that contrasts with what Jane Gallop (1988) called the pederastic "paradigm for classic European pedagogy" (p. 43). It is a pedagogy rooted in the confusion of living with children, or as Madeleine Grumet (1988) put it, rooted in that "delightful fusion of self and other that we call confusion" and that reappears "in the parenting of our own children" and that "also provides the possibility of caring for other people's children, [which is] the most serious and promising commitment of pedagogy" (p. 99). Grumet goes on to suggest that " $[\mathrm{w}]$ omen must remember and articulate the experience of child nurture so that we can bring what we know from the complex, sustained, and exciting labor of child care into the intellectual structures of the disciplines and the methods of pedagogy” (pp. 99-100). In this suggestion, Grumet provides a trace to Pestalozzi who spoke of the mother as the primary teacher. Indeed, a maternal pedagogy has come down to us through those such as Maria Montessori who cast education in terms of “communizing a maternal function” (Montessori, 1967, p. 66). 
Maternal thinking stands in sexual opposition to the paternal pedagogies, yet this kind of thinking risks closing down the question of ethics, appropriating otherness in gestures of "auto-affection" (Irigaray, 1991, p. 29) and reducing "women to the work of social reproduction either as mothers, wives, nurses and housekeepers to both children and men” (p. 196). What is required is not that we trace a pedagogy of the flesh back to the nurturing and caring functions of women, but rather that we learn to see how living with children requires an elementally passionate pedagogy. "We have," as Luce Irigaray (1991, p. 43) asserted, "to discover a language which does not replace bodily encounters, as paternal language attempts to do, but which can go along with it [sic], words which do not bar the corporeal, but which speak [the] corporeal." We need to embrace a gestural language of pedagogical intimacy, not limited to "erotic or familial relations" (Grumet, 1988, p. 109), yet nevertheless recognizing the sensuous shaping of our lives with children as they learn to become increasingly at home in an ever-expanding world. A pedagogy of intimacy can thus bring about a transformation of our relations to children through the gestural reminder of what living with children essentially, elementally and ethically requires of us.

\section{The Gestured Moment}

Transcendental ethics may serve as guides for teaching conduct, but only insofar as we remember to apply them. Likewise, memories may serve us, provided we think carefully about the body's memorability. Lived experiences as recollections that guide conduct, whether as personal recollections or socially constructed memories, prompt living experiences. They are of memories that Rainer Maria Rilke (1983) says are "caught in glance and gesture, nameless and no longer to be distinguished from ourselves” (p. 6).

The memorability of the moment is its tangibility. It lies with gestures that carry a distinctive "motor memory" (Merleau-Ponty, 1962, p. 140), a particular "melodic character" (p. 105), and a style of engagement. Our consciousness of the moment "is subtended by an intentional arc which projects round about us our past, our future, our human setting, our physical, ideological and moral situation, or rather which results in our being situated in all these respects," and insofar as it is "this intentional arc which brings about the unity of the senses, of intelligence, of sensibility and motility," we live most consciously in our gestures (p. 136).

David Michael Levin (1985) takes up these considerations of the inherent memorability of gesture and notes, in passing, the reference by Merleau-Ponty to the “embrace” as signaling the power of gestures (Levin, 1985, p. 141).

Each instant of the movement embraces its whole span, and particularly the first which, being the active initiative, institutes the link between a here and a yonder, a now and a future which the remainder of the instants will merely develop.... The scope of this inclusion is the measure of that of my existence; but in any case it can never be all-embracing [emphasis added]. The span and time which I inhabit are always in their different ways indeterminate horizons which contain other points of view. (Merleau-Ponty, 1962, p. 140) 
To embrace a child is to accent, even more profoundly than most other gestures, this inherent power of linking "a here and a yonder," a present and a future, because that which provides such a link is the memorable resonance in the initiation of the gesture. That instant is, there and then, here and now, "the measure of my existence" that I enact in the unfolding of the embrace, and its compass can be judged by its responsivity to and allowance for the child to be more fully himself or herself.

The embrace has been considered elsewhere (Smith, 2006). In the present analysis of the embodiment of good teaching I attend to an even more pedagogically intimate gesture - the caress - and describe phenomenologically its nature, form and function in teaching. I focus on the caress as a significant gesture of intimacy and, as such, one that enables a fuller sense, a tactile, kinesthetic, proprioceptive sense, of what constitutes the appropriate moment of good teaching. This work draws attention to a fundamentally gestured receptivity to the motions of another that has previously been described in terms of the elemental configurations of "vital consciousness" (Smith, 2007) and the relational dynamics of "animate consciousness" (Smith, 2011). Now I seek to move with the motioning of the caress through the phenomenological form of a vital, animating description of the relational dynamics that obtain between teachers and learners in schools and classrooms.

\section{The Caress}

The caress is a loving gesture. It is sensual, tinged with the erotic, yet it remains a gesture of connecting with another person in his or her bodily differences. Catherine David (1996) says it well:

The caress questions the other person in that person's intimate reality, that is, life experience. Is not love precisely that ability to recognize what the other person is feeling and to incorporate this knowledge into our actions and gestures? That is why the caress possesses all powers, at least when it beats with the pulse and truth of desire. It can bring peace, laughter, defect, pleasure, or tears, whatever. It diffuses delight and caprice throughout the skin, right into the roots of being. (p. 160)

The caress feels the presence of another in tracing the curve of an arm, the contour of a cheek. It recognizes, in bringing to the surface of our contact, to the light contact of hand and skin, another's deep emotions. The caress soothes, assuages, ameliorates the other's troubling moods and places there, at that otherwise turbulent site of connection, a calming, responsive hand. It traces a different emotional form, not rounding or molding that form as a massage therapist might do, but by merely suggesting, intimating, and deftly drawing that form through the lightness of bodily contact.

The caress distinguishes itself from other weightier touches. It is not a complimentary pat on the back, not a hand placed reassuringly on the shoulder, not a stroke of affection, not even a grazing, glancing brush of affection. It is much more and especially so when its lightness transcends these touches of emotional direction. The seeming ambiguity of the caress is carried in its lightness such that the full meaning of its particular motion is located at the site of contacting the body of another. The caress is surely motivated by the 
desire to reach out to another, however it moves most surely, most caressingly, when it is informed by the shape of another and by what the curve and shapely line tell of being with another most attentively, most lovingly. The caress can easily draw the other to me such that I can claim in its motions my desire for the other. The caress tingles in anticipation of further sensual, carnal connection. Yet it remains light when drawing me into the place of the other, enlarging that desire for the other through a tactile connection that still preserves a space for the other's embodied singularity. The lightness of touch keeps a space of respect, affection, empathy, and appreciation. It acknowledges not so much another's place beside me, but rather the place we share alongside one another.

Alphonso Lingis also has much to say about the power of the caress. It is a gesture that seems essentially to need another body, a receptive one, a body that is open to touch and that in large part determines the nature of that touch. "The hands that caress do not move with their own goals in view; they are moved, troubled by the touch of the other with which they make contact, afflicted with the pleasure and the torment of the other" (Lingis, 1994, p. 170). Caressing hands are softened in the contact with another. "They make contact with a vulnerability that summons them, a susceptibility that puts demands on them" (p. 171).

The vulnerability of the other person activates the caress. That vulnerability softens what might otherwise become groping, fumbling, clumsy motions. It diffuses a singleminded contact. In fact, the caress is not so much an act of consciousness as an opening to the world that fills us with a pre-consciousness of our kinetic-kinesthetic-affective connection to the world (Sheets-Johnstone, 2011) and to other vulnerable beings (SheetsJohnstone, 2008). It is a transcendence of self and openness to matters of the world beyond the narrow definition of the sensual or sexual. It is the critical moment of recognition of our being bodily, palpably in a universe which is reflected back in the condensed, concentrated form of what we are actually able to truly feel and touch. As soon as we sense another's vulnerability the caress becomes much more than a sensual act. Its tactile, kinesthetic, proprioceptive and even visual senses fill another's need. These senses hold a sense of the other person, guiding the hand to the site of another's vulnerability, not to create emotional dependence but rather to vitalize the other's sense of self and of what he or she might become.

“The person being caressed shines with happiness," writes Gaston Bachelard (1964, p. 39). The lover is innervated and sensuously charged. The beloved glows. The other, who is not my lover, also lightens with the touch of the caress. This person, the child, my friend or some other person opens to my touch, lights up in a smile. Beaming.

What motions create this bodily effect? What movements distinguish the caress as more than a sensual, erotic and sexual gesture or even as a casually light gesture of affection?

It seems the caress is not confined gesturally to any specific acts or motions. It can take many forms, involve many kinds of strokes, many rubbings, many grazings and brushings of the flesh. There are the "stale caresses that are all alike," "perilous caresses of the experts in amorousness," the "shadowy semblance of caresses," "filial caresses" and "mother embraces," the "soothing, velvety caress" of beef broth and "instinctive caresses" of "the forbidden fruit of love" (Huysmans, 1959). If there is a commonality then that is a function of the degrees of restraint to these various motions. Not conscious 
restraint, it is the case that the caress carries an intentional lightness of touch. The caress moves by virtue of its self-restrained touch.

It is thus that we can distinguish between different attachments in the caress. For instance, Gaston Bachelard (1964) writes of a "sublimation" of the passions that can be poetic or romantic in the sense of keeping "contact with the life of the passions" (p. 99). Alternatively, there can be a "sublimation of a different type that we shall call dialectical sublimation, in order to distinguish it from the continuous sublimation which is the only one envisaged by classical psychoanalysis” (pp. 99-100). The latter sublimation is based on "a joy in accepting limitations inherent in all joy of learning. It is insofar as it is joyful that a well-founded repression becomes dynamic and useful” (p. 100). One self-corrects, informing action and performing in an ethical register what might otherwise be selfindulgent and reductively subjective. In the case of the caress, this self-correction is not as overtly conscious as the thesis of "dialectical sublimation" might suggest; nevertheless there is the joyful restraint of responding to another who profits by a caress that is given freely without any claim to an emotional return. A better way of saying it is that the caress is potentially full of care.

David Michael Levin (1999), referring to Heidegger's notion of “care,” indicates for us this carefulness in the caress. He writes:

[W]e are appropriately caring when we relate "to the thing in hand according to its nature," thus "letting that nature become manifest by the handling," and letting ourselves - our hands, our gestures-be appropriated by the presencing of the thing....The tender, caring touch, which feels what it touches with a reverence that is also active "aesthetic" appreciation, gets in touch with a thing's essential nature more deeply and closely than the hand which willfully grasps and clings, moved by desire (i.e. attraction and aversion), or than the hand which is indifferent to the beauty of the thing in the disclosure of its truth, its ontological dimension of difference. (p. 139)

The caress is responsive in its touch to the contact it makes with another. That vital, selfanimating and other-animating, contact is not only tactilely and kinesthetically caring, it also finds proprioceptive meaning in the balance of desire and longing with vulnerability and need. It is invoked by the call of the other, literally in murmurings, sounds, utterances, solicitations and articulations, to which the feeling response is more attuned than "our other perceptual capacities" (Levin, 1989, p. 219). The silence of a caress is the gathering of a heard carefulness, a fully attentive listening, which invariably extends the contact of the caress through soothing, saving words issuing from this silence. Vision, too, seemingly the most distancing and hegemonically careless sense (Levin, 1993), carries the perceptual promise of a loving gaze that sees the fullest becoming of another. It holds, not a blindness, but a diffusion of the clear, objectivizing sight lines that bring close the vision of another. There is more than the silence of the audibly listening self and more than the proximities and positional reciprocities of the seeing self. The corporeality of the caress harkens to what Levin refers to as the "echoes of responsibility" (KleinbergLevin, 2007) in the "gestures of ethical life" (Kleinberg-Levin, 2005) and which can be described more directly and contextually as gestural resonances of pedagogical 
relationality. The caress is inherently, multi-sensorially and essentially, tactilely careful and none more so than in the caress of a child.

\section{A Child Caress}

The pedagogical register to the carefulness of the caress is found in the literal and figurative 'conception' of children. For it is in careful responses to the vulnerability of the child that he or she is not only nurtured but also discovered. In other words, beyond the biological facts of life there is a pedagogical conception of the child that is attained in carefulness, in motions of care, in caresses, "like a mother's caresses, testing and proving the bulk of the child, making sure it is whole and round” (Elkins, 1996, p. 128).

Lori Driussi (2002) is a classroom teacher who knows of such caresses. She writes in the following anecdote of a maternal caress that informs her teaching, that sensitizes her to the children in her charge, and that makes possible the relations she establishes with those children.

My body remembers my mother's touch, the security of her presence, the tenderness of the strokes that soothed the headache. Aunt Gloria said it was "unusual for a little girl." Tiny ears bones [sic] strained toward the soft voice weaving the story of her hands' automatic knowing. A mother's comfort, not intellectualized, but simply done as one body engaging with another.

"Make sure she lies still!" says a grave, commanding voice. The clanking of cold metal and blue plastic assaults my ears and alerts my fears. The efficient swish of polyester between thighs of medical technicians brings gravity to the room and I am grateful for the maternal voice and gesture.

"Let's plant a flower," my mother intones. "First we must loosen the dirt, turn it over for air." She carefully conjures a seedbed in the folds of my outer ear. Her words are collected and sent floating...drifting through my body, sprinkling relaxation on tense tissue and bated breath. "Then we make a hole, just the right size for the seed and place it in gently." The soil of my ear garden is smoothed and opened to receive this kernel of distraction and comfort.

My mother sits at my back, on guard and protective as my body lies compliantly in a fetal position, completely still on the outside. Inside, defiantly, my own rhythms race on: heart beating, lungs breathing, stomach clenching, synapses firing.

"There now, the seed is sown and we'll cover it with dirt for protection so it can grow slowly and come up strong in the Spring." My body gratefully receives the small circles of love and tenderness that caress my trepidations. I feel the fertile earth warmed by my mother's tender, 
nourishing motions that will see the seed germinate and, in its time, blossom within my healthy body.

The medical technician says: “Okay Lori, we're going to put a needle in your back. It will sting a little bit and you might feel like moving. You must stay still. If you straighten your spine, the needle could break.”

I am cold. My mother's story spins rhythmically, weaving a magic blanket, cocooning my body with whispers of assurance. "It's okay. Let's water the seed." My body, unable to see her, hangs on to and is fortified by her gallant voice and balming touch. (pp. 15-16)

Lori's recollection draws attention to the caress that lightens the child's situation where otherwise more business hands prevail. In a situation of care-giving, there is the gesture that is most caring.

To caress the child is to approach that child in his or her most vital dimension (see Irigaray, 1991, p. 179). Teachers know this in the negative through the prohibitions against touching children and in the pedophilic disgust of caressing that is really fondling. But positively speaking, teachers know that caresses establish contact with the child's vital dimension through such obviously caressing gestures of teaching as a congratulatory hug, a comforting embrace, a pat on the back, and gentle, loving touches. They also know of the child's vitality through motions that smooth the awkwardness of the child's actions, gestures that guide a child's attempts at throwing a ball, that enable the child to hold a crayon and play a keyboard. Subtler caresses of teaching are evident in hanging a child's picture in a prominent place, gathering the class in for show-and-tell, and even in the personal touches of written feedback on a child's assignment. One can speak to a child, from the heart, letting one's voice soothe and assuage an otherwise difficult or even painful situation.

Even more subtle caressing gestures are those of the eyes, especially in the glance "that tarries with what is seen" (Buytendijk, 1968, p. 218), resting on the child and gliding over things the child is doing. This thoughtful, restful gesture of the eyes breaks the hold of a teacherly look that ensures distance between adult and child, for the sake of observing more fully, appreciatively and helpfully the child's motions. In gliding over a scene and coming to rest upon a child, this tarrying glance carries the thoughtfulness of "a person of mature humanity" (p. 220) for one whose maturity is still at issue. This is not the dreamy look of indifference, nor it is the erotically-charged look "that ensnares both teacher and student in their reciprocal gaze” (Grumet, 1988, p. 115); it is "a glance that radiates from an immanence opening itself out and that testifies to a simple 'Mitsein,' a 'being-together-with' without any ulterior motive” (Buytendijk, 1968, p. 219). In this caress of the eyes one notices a relaxation of the teacherly position, an absence of selfconsciousness, a self-abnegation, or better still, a transcendence of self in the direction of the child. The interiority from which the gesture appears to emanate need not be inferred behind an otherwise crusty teacher outlook; it is evident in the adult's enjoyment of, and absorption in, the moment.

François Delsarte in a letter written to the King of Hanover distinguished between two related looks that have to do with either sensuality or tenderness. 
The former of these glances is addressed exclusively to the form of its object; it caresses the periphery of it, and the better to appreciate its totality, moves away from it....The other look, on the contrary, aims at the heart of things without pausing on the surface, disdaining all that is external. It strives to penetrate the object to its very essence, as if to unite itself more closely within it; it has the expression of confidence, of faith in a word, the giving up of self. (as cited in Zorn, 1968, p. 49)

Such is the tenderness of mother and child, as in a Mary Cassatt painting, where the caress is drawn to the integrity of the child's movement and the child's attentiveness to things and objects of its self-realization. The caress has the tenderness of a prayer for the child's becoming, just as "[i]n our desire to have the thing we pray for, we clasp our hands together and press them to our bosom as if we already held it” (Zorn, p. 114).

It seems the eyes do not just caress as a gesture; they receive the caress, which emanates from a gesture. The viewer is not the center of the experience. On the contrary, there is an active force sending the caress. The "fecundity of the caress," as Irigaray (1991) terms it, achieves a relation to the child that draws him or her close to that which the teacher wants to show while still palpably maintaining the "irreducible incarnation" of the child and ultimately leaving the child to his or her "own generation" (p. 181, 183). It is this "fecundity of the caress" that moves what would otherwise be an erotic relation in the direction of pedagogic tactfulness. It takes us beyond the "fecundity of the I" which, according to Emmanuel Levinas, casts our living with children as "a relation with a stranger who while being Other...is me, a relation of the I with a self which yet is not me” (p. 277). Critiquing Levinas' sense of the child-as-Other, Irigaray (1991) asserts:

The child should be for himself not for the parent. When one intends to create a child, giving the child to himself appears as an ethical necessity. The son should not be the place where the father confers being or existence on himself, the place where he finds the resources to return to himself in relation to this same as and other than himself constituted by the son. (p. 181)

Accordingly Irigaray (1992) writes of the 'fluid caress' that blurs the boundaries between two persons.

Your skin and mine, yes. But mine goes on touching itself indefinitely, from the inside. Secreting a flow which brings the sides together. From which side does that liquid come? One or the other? Both? So which is one and which is other in that production? Neither? Yet it exists. Where does it come from? From both. It flows between. Not held or held back by a source. The source already arises from the two caressing. (p. 15)

This caress is the "touching-touch" that Merleau-Ponty (1968) presented as the sensible paradigm for our implication in the world. Yet Irigaray's description of this gesture, which admittedly is essentially sexual, is suggestive of the kind of caress that embodies 
an almost seamless pedagogic intentionality. Such a caress traverses the distance that would otherwise separate adult and child. It acknowledges, with Merleau-Ponty (1968), that "[w]hen I perceive the child, he is given precisely in a certain divergence" (p. 203), yet still I can establish a reversibility, not grounded in an appropriation of the child's perspective, but rather, in what Merleau-Ponty maintained to be the recollection of a "new reversibility and the emergence of the flesh as expression" (pp. 144-145).

The fluid caress would seem, for Merleau-Ponty, to be indicative of "a reversibility always imminent and never realized in fact" (p. 147), a "reversibility that defines the flesh" (p. 144) as "a general thing, midway between the spatio-temporal individual and the idea, a sort of incarnate principle that brings a style of being wherever there is a fragment of being. The flesh is in this sense an 'element of being'" (p. 139) or "the concrete emblem of a general manner of being” (p. 147). For Irigaray, however, the caress instantiates an actual mutual and reciprocal touching of individuals who are in and of the sensuous, material flesh (Grosz, 1994, pp. 103-107). But, rather than a touching that isolates individuals from the world, the fluid caress outlines an intercorporiety that, more than being together with children in the world, is living with them from the world (see Levinas, 1969).

The caress is traced by a world that is not so much brought to bear upon our living with children as it is 'fleshed out' in the gestures of that relationality. "Everything depends, that is, upon the fact that our glances [and our gestures in general] are not 'acts of consciousness,' each of which claims an invariable priority, but openings of our flesh which are immediately filled by the universal flesh of the world" (Merleau-Ponty, 1964, p. 16). We could say that the fluid caress flows from the fluidity of the world and that, in this gesture where "the material, sensual presence of the world draws the one who teaches and the one who learns to each other as they approach it” (Grumet, 1988, p. 108), the child comes into pedagogical being.

\section{Teaching Caresses}

Sherwood Anderson's (1960) story of the teacher, Wing Biddlebaum, tells us a great deal about the pedagogical effects of caressing hands.

Wing Biddlebaum talked much with his hands. The slender expressive fingers, forever active, forever striving to conceal themselves in his pockets or behind his back, came forth and became the piston rods of his machinery of expression....

In his youth Wing Biddlebaum had been a school teacher in a town in Pennsylvania. He was not then known as Wing Biddlebaum, but went by the less euphonic name of Adolph Meyers. As Adolph Meyers he was much loved by the boys of his school.

Adolph Meyers was meant by nature to be a teacher of youth. He was one of those rare, little-understood men who rule by a power so gentle that it passes as a lovable weakness. In their feeling for the boys under their 
charge such men are not unlike the finer sort of women in their love of men.

And yet that is but crudely stated. It needs the poet there. With the boys of his school, Adolph Meyers had walked in the evening or had sat talking until dusk upon the schoolhouse steps lost in a kind of dream. Here and there went his hands, caressing the shoulders of the boys, playing about the tousled heads. As he talked his voice became soft and musical. There was a caress in that also. In a way the voice and the hands, the stroking and the shoulders and the touching of the hair were a part of the schoolmaster's effort to carry a dream into the young minds. By the caress that was in his fingers he expressed himself. He was one of those men in whom the force that creates life is diffused, not centralized. Under the caress of his hands doubt and disbelief went out of the minds of the boys and they began also to dream. (pp. 27-28)

Sue Montabello also knows the powerful effects of caresses. As a school principal, Sue must continually intervene in situations where others often impose heavyhandedness. She chooses, instead, to bring the lightness of the caress to bear upon them. Sue writes of a fairly typical scene.

I hear loud sobbing and crying coming from the next room. I stand up, leaving Jacob who has been sent to me, with defiance and anger still bouncing off the walls. I walk by Sam, grabbing at my arm to let me know he is anxious to talk to me after his intense outburst yesterday.

As I move into the room adjourning mine I see Jesse spread out on the floor crying. Through sobs he tells me his teacher won't give him his treasured toy. "All I want is to have it back. It's mine," he gasps through ever increasing sobs. I sit down beside him saying nothing. I know Jesse, who is new to our community this year, lives with many complexities in his life outside school. I know his crying may be much less about his toy than his world.

I crouch down on the floor and begin to rub his hair, comforting him with quiet words. "It's okay, Jesse," is all I say as I continue to run my hands through his hair. As I sit beside him soothing him with my gesture, his sobs begin to subside.

Looking up to the doorway, I see both Jacob and Sam standing there watching us. "Is he okay?" Sam asks, the gentleness of his words letting me know he is genuinely concerned. Jacob says nothing, but his body has softened as he watches. We stay there for a moment, me on the floor beside Jesse comforting him, Sam and Jacob standing at the door, watching on. 
Jesse's sobs subside and he sits up, looking at the boys, waiting for them to come to him. Sam smiles easily in return. Jacob shrugs his shoulders and forces back a grin, not yet willing to let down his guard.

I also feel a softening in myself. Moments earlier I had felt a growing frustration with Jacob's anger and his seeming unwillingness to talk about it. Even though I knew so well that Jacob needed the space to work it out, and that the sand table was often the place in which he found refuge, I could feel the pressures of the institution growing. A voice was saying: There needs to be a serious response to Jacob's actions. He physically hurt another child. What about our school district's policy of "zero tolerance for violence"? What about the child who was the victim of the slashing? What about that child's mother, who I knew would want to see some action taken to ensure her child's safety? What about the other children involved? What about the child's teacher and this teacher's need to reassure others there was a response? I was beginning to respond to Jacob as the School Principal until Jesse's cries had pulled me away.

I was feeling the pressure of resolution, of moving to solution on this quickly so I could let everyone know "all was well.” But just as I was beginning to respond to Jacob as the Principal, Jesse's cries had pulled me away.

Now, in this moment, I come to Jesse as a woman, a mother trying to soothe a troubled child. The gesture of rubbing his hair, gently soothing him, returns me to that place had been so many times before with my own son. The walls that were beginning to build up to ready me for my “official response” to Jacob fall away. I feel at home as I sit and gently rub Jesse's hair.

The rhythmic actions of my hand moving through Jesse's hair return me to being a mother. For a moment I am no longer with Jesse but with my own son, BJ, as a child. This moment somehow transforms us all. In this moment we are no longer students and Principal, but children and parent. No words are spoken to that effect but somehow we all recognize it.

I get up off the floor and Sam reaches out his hand to help me up. Jacob moves into the room, picks up the foam ball, and throws it to Jesse. Jesse laughs. (Montabello, 2008, pp. 151-152)

Sue Montabello invokes motherhood, but not simply to justify the relation established with the child. Instead she has found the higher relationship connected to that earlier definition of the care of the caress: she becomes her own child, sees her own motherhood and childhood reflected to her, and caresses the moment (in the form of this child) as pure duration. Her body is the child, her skin and blood and being, and for a moment she has 
touched what Grumet calls the "material, sensual presence of the world" which "draws the one who teaches and the one who learns to each other as they approach it" (Grumet, 1988, p. 108).

The pedagogical effect of the caress is essentially affective. Children feel better in being comforted, seen, heard and spoken to in a caring manner. In doing so, they are helped to expand their horizons of meaning-making, thus admitting a cognitive value to the significance of the gesture. The boys in Wing Biddlebaum's class "begin to dream" while those in Sue Montabello's charge learn what lies beyond the rules of conduct to discern the situational obligations of caring for one another (Noddings, 1984). They learn to care for one another and for the possibilities of what they might become. Yet this effect ought not limit us from recognizing also the preconditions of a caring responsiveness that are not subsumed under the "natural" and "ethical" caring distinctions which Nel Noddings makes (pp. 79-84). Those sustaining and perduring preconditions have much to do with the kinetic-kinesthetic-affective dynamics of the caring gesture itself. The motions of the caress do not just occur in the space between the one caring and the one cared for; these motions, in their qualitative movement dynamics, actively create that space as an affective attunement of one to another (Sheets-Johnstone, 2008, pp. 200-203). The "tact of teaching" (van Manen, 1991) is essentially rooted in a spatializing intercorporeity that is the basis of sympathy, empathy, compassion and the attendant virtues of relationality to which we lend cognitive and moral decision-making capacities. Yet, first and foremost, there are living bodies, teachers and children, for whom the gesture itself, in its tactile immediacy, is paramount.

\section{Lasting Gestures}

"We meet each other first through body and gesture" says Max van Manen. "Tact is mediated through gesture” (van Manen, 1991, pp. 181-183). David Abram writes:

Through gesture we body-forth into the world. The hand that beckons, the gaze that caresses, the voice that soothes, the smile that radiates warmth, and the stance that shouts "No!", the look that pierces, the voice that chills, the chin that distances - all these gestures resonate within and around us. There is an unspoken recognition that "facial expressions, gestures, and spontaneous utterances like sighs and cries seem to immediately incarnate feelings, moods, and desires without 'my' being able to say which came first - the corporeal gestures or its purportedly 'immaterial' counterpart. (Abram, 1996, p. 74)

Additionally, Catherine David (1996) informs us that: "No less than words (but perhaps we should consider them a different kind of words), gestures are the basis of our relationships with others” (p. 159).

Pedagogy, itself, is cultivated through gestures of daily life. Many teachers, much like Wing Biddlebaum, talk much with their hands. Paulo Freire was also a hand talker.

His light, expressive hands had a remarkable delicacy. His honey-coloured eyes revealed the sweet knowledge of his intelligence and his great 
kindness. Many who had the opportunity to talk to Paulo can clearly remember to this day how that meeting felt; how it felt when Paulo softly touched their shoulders as he liked to do, or when he looked firmly into their eyes, as fair and gentle people do....Paulo's act of touching while looking at people made the act of touching, an act so natural in our Brazilian culture, more than body to body contact. Touching with his hand and with his look, Paulo somehow connected his whole being, his reason and emotion, to the whole being of another person. (Freire, A., 1998, p. 3)

It is interesting that Freire's wife, Ana, recalls Paulo's teaching in this gestural way. Amidst all the books on pedagogy that Freire wrote, in all the pedagogical work he did, it all comes down to the way he touched others "with his hand and with his look." "The mannerisms, the quirks, the stray parentheses of our teachers remain fixed in memory long after we have forgotten the pieces of evidence or marshaled ones of reason they urged on us when we sat before them, docile, complaisant, all ears” (Long, 1995, p. 13). Their primary pedagogical effect is a lingering gestural one.

Rainer Maria Rilke (1978) not only knew how memory is caught in gesture, he also knew much about the gestures themselves and their lasting value. He wrote in the second of the Duino Elegies "the caress lasts/ because what you cover/ so tenderly/ does not disappear/ because you can sense/ underneath the touch/ some kind of pure/ duration” (p. 9). There is fullness to the moment of the caress, a plenitude, an abundance of affectivity, that lingers. There is a temporal sense of being fully present and that presence extending far into the future, although in the first instance there is a kinesthetic sense of duration, of flow and circulations that make the caress seem lasting. Of course the caress can be readily dismissed; it can easily be missed; the tender moment can turn momentarily into something unseemly, profane and best forgotten. But the caress can last as an eternity in the moment, although "[e]ternity here does not refer to an endless prolongation of linear time, as it often does in common usage. It indicates, rather, the awareness of the absolute reality of being, intersecting with the temporal sequence of its unfolding at every moment" (Kohák, 1984, p. 18). Eternity in the moment is about the 'purity' or goodness of the caress and not just its lingering affect, which surely wanes. Eternity in the moment is the inherent sense of goodness, rightness, appropriateness, tactfulness and thoughtfulness that gives the caress lasting effect. Erazim Kohák tells us that: “The beauty of a trillium, the truth of an insight, the goodness of a gesture of kindness, or the pain of tragedy have their absolute value, ingressing in time but independent of it" (pp. 18-19). The purity of the caress, which we earlier referred to as its carefulness, is that which lasts underneath its touch.

Kohák says one must have the "ability to discern the moral in the vital” (p. 19), to which can be added, one must learn to see the moral in time-bound motions, not just as "ingressing in time but independent of it," as being of the felt quality of movement, its animation and emotion, and its effect and affect beyond the moment. It is not that time yields to "the wisdom of eternity, which sees, behind time's pleasures and annoyances, the eternal value of every fragment of what is good, true, beautiful” (p. 46), it is that there is the fullness of time in which goodness, truth and beauty become manifestly evident in compelling gestural moments. "Eternity, so understood, is not an extension of time, not 
even an infinite time. It is, rather, a vertical dimension cutting through time at each of its moments” (p. 82).

A human is the being capable in each moment of reaching out beyond the order of time to eternity. It is the human, in the recognition of the goodness, truth, beauty, and holiness of being, caught up in its temporality, who brings out its absolute validity, its dimension of eternity. (p. 83)

What is crucial is that humans, whether they do so or not, are capable of encountering a moment not simply as a transition between a before and an after but as the miracle of "eternity ingressing into time" (p. 85). Eternal time is of the essence in the careful, caring gesture that makes contact with the lifetime of another.

\section{Conclusion}

When is the caress sensual? When is it beautiful? When is it telling? When is it appropriate, tactful, and the right action? When is it pedagogical? Ethics come into view with these questions, and not just because there is always the worry that the gestured relation to children may be erotic in the sexual sense. Ethics comes into view because the lingering affect of the gesture is to develop a relation to the child and to the world that the child is being educated to inhabit. The lingering affect of the caress, which is felt as kinesthetic resonance, is also an effect of kinesthetic consciousness that awakens the senses to pedagogical sensitivity, of tact and contact that is careful and prudent. That must surely be the "inner touch" (Heller-Roazen, 2007) of teaching-the sense that is made, moment-to-moment, of what is sensible to do here and now for this or that particular child.

The caress can never be solely a kinesthetic gesture. There is necessarily a "holding back," a "reserve," that is essential to an "ethics of the delicate touch" (Connor, 2004, p. 279) of the pedagogical caress. This "reserve" is a thoughtful apprehension of the motions of the caress that are enacted in the ongoing practices of daily life and our pedagogical relations. By the same token, purity or goodness is not ultimately a matter of carefulness; in fact, carefulness becomes at a certain point a block to the kinesthetic flows and circulations of desire that bring the caress to life. It may thus serve us well to coin a new word, kinethics, to avoid any hint of ethics that exist just in the abstract and are subsequently imposed on bodily practices or ethics that give way to bodily indulgences.

Pinning the good of teaching on the caring caress involves recognizing how the "lifeworld existentials" of "lived body, lived space, lived time and lived relation to the other" necessarily and sufficiently "form an intricate unity which we call the lifeworld (van Manen, 1990, pp. 101-106). The neologism kinethic is intended in its suffix to draw particular attention to the "primacy of movement" (Sheets-Johnstone, 2011) and to the kinetic and kinesthetic features of gestured movements that configure our bodies in relation to others, that spatialize a space of receptivity to others, that hold a moment agogically, and all for the sake of giving substance, shape and enduring value to learning to live well with one another. It may be said that there is beauty in the particular gesture, however such beauty can best be acknowledged as the form impression (aesthetic) of 
sensations (aisthesis) and motional feelings (kin-aisthesis). The caress, as the prime kinethic gesture, allows us now to cast our phenomenological eyes to other actions, other gestures, other motions and, indeed, looks, words and planned and structured actions that extend the lived and living bodies, spaces, times, and relations of teaching. For what is good about teaching is always an achievement amidst the dailiness and defined spaces, places and times of living well with children.

Kinethics are essentially actions and interactions of inherent goodness, which is to say, postures, positions, expressions and particularly gestures that move us closer to our best selves. The momentarily given yet timelessly received caress is one such gesture and a representative one at that of what moves adults and children to become their best selves. This movement is essentially rooted in bodily animation, in the ebbs and flows of bodily fluids, in musculature that attunes its motions to the undulations of another, in bodily consciousness that senses the shapes and forms of another from the heart to the hands. Kinethics is an aesthetics, a synaesthetics and kinaesthetics. It is also a tactile register of the movements of another and, at times, a haptics and an optics of what those movements should become. The ethical moment of the caress is the kinetic imperative to respond to the other's vulnerability in a way that guides and directs the other to become his or her better self. This pedagogical caress is prompted not so much by vulnerability for which transcendental ethics are called for but by recognition of a moment's duration and as remembrance of what the momentary encounter with the child portends. Rather than inserting ethics into the encounter, the task of good teaching is to enact and sense fully the lasting value of those good moments that make up a good life for and with others.

\section{References}

Abram, D. (1996). The spell of the sensuous: Perception and language in a more-thanhuman world. New York: Vintage Books.

Anderson, S. (1960). Hands. In Winesburg, Ohio (pp. 27-34). New York: Viking Press.

Bachelard, G. (1964). The psychoanalysis of fire (A. C. Ross, Trans.). Boston: Beacon Press.

Barreca, R., \& Morse, D. D. (1997). The erotics of instruction. Hanover: University of New England Press.

Buytendijk, F.J.J. (1968). Woman: A contemporary view. New York: Newman.

Connor, S. (2004). The book of skin. Ithaca, NY: Cornell University Press.

David, C. (1996). The beauty of gesture: The invisible keyboard of piano and T'ai Chi. Berkeley: North Atlantic Books.

Driussi, L. A. (2002). Cultivating risk: A teacher-gardener's journey (Unpublished M.A. thesis). Simon Fraser University, British Columbia. 
Elkins, J. (1996). The object stares back: On the nature of seeing. New York: Harcourt Brace.

Freire, A. M. A. (1998). Paulo Freire: To touch, to look, to listen. Convergence, 31(1/2), 3-5.

Gallop, J. (1988). Thinking through the body. New York: Columbia University Press.

Gallop, J. (Ed.). (1995). Pedagogy: The question of impersonation. Bloomington: Indiana University Press.

Grosz, E. (1994). Volatile bodies: Toward a corporeal feminism. Bloomington: Indiana University.

Grumet, M. R. (1988). Bitter milk: Women and teaching. Amherst: University of Massachusetts.

Heller-Roazen, D. (2007). The inner touch: Archeology of a sensation. New York: Zone Books.

Huysmans, J.K. (1959). Against nature (R. Baldrick, Trans.). Baltimore: Penguin.

Irigaray, L. (1991). The Irigaray reader (M. Whitford, Ed.). London: Basil Blackwell.

Irigaray, L. (1992). Elemental passions (J. Collie \& J. Still, Trans.). London: The Athlone Press.

Kleinberg-Levin (2005). Gestures of ethical life: Reading Hölderlin's question of measure after Heidegger. Stanford: Stanford University Press.

Kleinberg-Levin, D.M. (2007). Before the voice of reason: Echoes of responsibility in Merleau-Ponty's ecology and Levinas's ethics. New York: State University of New York Press.

Kohák, E. (1984). The embers and the stars: A philosophical inquiry into the moral sense of nature. Chicago: The University of Chicago Press.

Levin, D. M. (1985). The body's recollection of being: Phenomenological psychology and the deconstruction of nihilism. London: Routledge and Kegan Paul.

Levin, D.M. (1989). The listening self: Personal growth, social change and the closure of metaphysics. New York: Routledge.

Levin, D. M. (1993). Modernity and the hegemony of vision. Berkeley: University of California Press.

Levin, D. M. (1999). The ontological dimension of embodiment: Heidegger's thinking of being. In D. Welton (Ed.), The body: Classic and contemporary readings (pp. 122149). Malden, Mass.: Blackwell. 
Levinas, E. (1969). Totality and infinity: An essay on exteriority (A. Lingis, Trans.). Pittsburgh: Duquesne University Press.

Lingis, A. (1994). Foreign bodies. New York: Routledge.

Lingis, A. (1998). The imperative. Bloomington: Indiana University Press.

Lingis, A. (2000). The elemental imperative. In L. Hass \& D. Olkowski (Eds.), Rereading Merleau-Ponty: Essays beyond the continental-analytic divide (pp. 209232). New York: Humanity Books.

Long, B. (1995). Mind's bodies: Thought in the act. Albany: SUNY Press.

McWilliam, E. (1994, November). (S)education: A risky inquiry into pleasurable teaching. Paper presented at the AARE conference, University of Newcastle Australia.

Merleau-Ponty, M. (1962). Phenomenology of perception (C. Smith Trans.). London: Routledge and Kegan Paul.

Merleau-Ponty, M. (1964). Signs (R.C. McCleary, Trans.). Evanston: Northwestern University Press.

Merleau-Ponty, M. (1968). The visible and the invisible. (A. Lingis, Trans.). Evanston: Northwestern University Press.

Milloy, J. (2007). Persuasions of the wild, writing the moment: A phenomenology (Unpublished doctoral dissertation). Simon Fraser University, British Columbia.

Montabello, S. (2008). Journeying into the heart of schools: Dwelling in time, place and intimacy (Unpublished doctoral dissertation). Simon Fraser University, British Columbia.

Montessori, M. (1967). The Montessori method (A. George, Trans.). Cambridge: Robert Bentley.

Noddings, N. (1984). Caring: A Feminine Approach to Ethics and Moral Education. Berkeley: University of California Press.

Rilke, R. M. (1978). Duino Elegies (D. Young, Trans.). New York: Norton.

Rilke, R. M. (1983). The notebooks of Malte Laurids Brigge (S. Mitchell, Trans.). New York: Random House.

Sheets-Johnstone, M. (2008). The roots of morality. University Park, Pennsylvania: The Pennsylvania State University Press.

Sheets-Johnstone, M. (2011). The primacy of movement (2nd ed.). Amsterdam: John Benjamins. 
Smith, S. J. (2006). Gesture, landscape and embrace: A phenomenological analysis of elemental motions. Indo-Pacific Journal of Phenomenology, 6(1). Retrieved from http://www.ipjp.org/.

Smith, S.J. (2007). The first rush of movement. Phenomenology \& Practice, 1(1), 47-75.

Smith, S.J. (2011). Becoming horse in the duration of the moment. Phenomenology \& Practice, 5(1), 7-26.

Snowber, C. (2006). A curriculum of longing. Journal of Curriculum Theorizing, 22(1), 79-88.

van Manen, M. (1990). Researching lived experience: Human science for an action sensitive understanding. New York: State University of New York Press.

van Manen, M. (1991). The tact of teaching. New York: State University of New York.

Weiss, G. (1999). Body images: Embodiment as intercorporeality. New York: Routledge.

Zorn, J. W. (1968). The essential Delsarte. Metuchen, NJ: Scarecrow Press. 